\title{
Impaired Pulmonary Clearance of Pneumococci in Neonatal Rats
}

\author{
J. DONALD COONROD, MILFORD C. JARRELLS, AND RAYMOND B. BRIDGES \\ Departments of Medicine, Veterans Administration Medical Center and the University of Kentucky Medical \\ Center and the Department of Oral Biology, University of Kentucky Medical Center, Lexington, Kentucky 40536
}

\begin{abstract}
Lung infections are a common cause of morbidity and mortality in neonates. To evaluate neonatal lung defenses against pneumococci, we challenged rats with aerosols of encapsulated pneumococci in an airborne infection apparatus. Whereas adult rats cleared $>95 \%$ of inhaled type 1 or type 25 pneumococci within $4 \mathrm{~h}$, pneumococci proliferated in the lungs of newborn rats and reached $200-600 \%$ of the baseline value by $4 \mathrm{~h}$ and $1000-1700 \%$ by $24 \mathrm{~h}$. As neonatal rats matured, their ability to clear inhaled pneumococci improved, but compared with adults some impairment in clearance was present until approximately 4 wk of age. Newborn rats had significantly fewer resident alveolar macrophages per $\mathrm{g}$ of lung tissue than did adults $(p<0.001)$. Although the number of resident macrophages increased with time, a significant deficit in alveolar macrophages persisted for the first 3 wk of life $(p<$ 0.01). Aerosols of pneumococci caused an influx of granulocytes into the lungs of adult rats within $4 \mathrm{~h}$, compared with $24 \mathrm{~h}$ for neonatal rats. Even at $24 \mathrm{~h}$ after pneumococcal challenge, newborn rats had significantly fewer granulocytes per $\mathrm{g}$ of lung tissue $(p<0.05)$ than did adults, although 7-day-old rats had reached an adult level by this time. Significant $(p<0.05)$ increases in granulocyte chemotactic activity were observed in lavage fluids of adult, but not newborn, rats after pneumococcal challenge. Thus, impaired clearance of pneumococcal aerosols by neonatal rats was associated with an age-dependent deficiency in numbers of resident alveolar macrophages and impaired generation of chemotactic activity and recruitment of granulocytes to the lung. (Pediatr Res 22: 736-742, 1987)
\end{abstract}

Abbreviations

PBS, phosphate-buffered saline

i.p., intraperitoneal

FMLP, N-formyl methionyl leucyl phenylalanine

Respiratory infections cause much morbidity and mortality in neonates, but only in recent years have detailed investigations of neonatal pulmonary host defenses been carried out. In rabbits, aerosols of Staphylococcus aureus (1) and group B streptococci (2) are poorly cleared in the first few weeks of life, particularly in the immediate postnatal period. In comparison with adult rabbits, neonatal rabbits have decreased numbers of resident

Received May 11, 1987; accepted August 11, 1987

Correspondence and reprints J. Donald Coonrod, M.D., Department of Medicine, University of Kentucky Medical Center, 800 Rose Street, Lexington, KY 40536 .

Supported by the Veterans Administration and by grant R01-HL31565 from the National Heart, Lung and Blood Institute, National Institute of Health, Bethesda, MD. pulmonary alveolar macrophages, and decreased bactericidal activity of alveolar macrophages for strohylococci $(3,4)$ and group B streptococci (2). In the present studies, pulmonary clearance of pneumococci was studied by use of a sublethal, inhalation challenge in rats. Clearance of pneumococcal aerosols was profoundly depressed in newborn and developing rats. Neonatal rats had lower numbers of resident alveolar macrophages than did adults, and impaired ability to generate chemotactic activity and to recruit granulocytes to the lungs.

\section{MATERIALS AND METHODS}

Animals. Sprague-Dawley rats with an established date of pregnancy were obtained from Harlan Sprague-Dawley, Inc., Indianapolis, IN. Rats were housed in plastic boxes under positive pressure ventilation with filtered air. Unweaned rats were kept with their mothers. Rats were given food and water ad libitum. During studies of bacterial clearance, unweaned rats were removed permanently from the colony along with their mothers. Developing rats of either sex were used as available for studies. Unless indicated otherwise, adult rats were at least 4 months old.

Bacteria. Pneumococcal serotypes 1 and 25 were obtained from the American Type Culture Collection, Rockville, MD. Encapsulation was maintained by periodic intraperitoneal passage in mice. Pneumococci were grown overnight under $5 \% \mathrm{CO}_{2}$ in brain heart infusion broth containing $7 \%$ heat-inactivated serum and were then inoculated into fresh media and incubated another 5-6 h to obtain log-phase growth. The organisms were washed in PBS (pH 7.4) and brought to a concentration of about $5 \times 10^{8}$ viable pneumococci per $\mathrm{ml}$ for nebulization. The number of viable pneumococci in slurries was determined by serial dilution and culture on agar plates containing $5 \%$ sheep blood.

Bacterial clearance. Clearance was carried out as previously reported (5). Briefly, log-phase pneumococci in PBS were aerosolized with a no. 40 nebulizer (The DeVilbiss Co., Somerset, PA) into an airborne infection apparatus (Tri-R Instruments, Rockville Center, NY) with a switchable in-line particle sizer (Andersen Samplers, Atlanta, GA). More than $85 \%$ of the particles were $<3.3 \mu \mathrm{m}$ as determined by cultures of the aerosol collected on Andersen air sampler plates. Rats were placed in individual compartments in the chamber to prevent huddling. Nebulization was carried out for $30 \mathrm{~min}$ and was followed by a 10 -min washout period before the animals were removed from the chamber. Rats were killed by an overdose of pentobarbital administered intraperitoneally immediately after removal $(0 \mathrm{~h})$ or at intervals thereafter. Lungs were removed aseptically, and the parenchyma was stripped from the large airways into $4 \mathrm{ml}$ of PBS in glass vials and homogenized (Tissumizer, Tekmar Co., Cincinnati, $\mathrm{OH})$ for $1 \mathrm{~min}$. Aliquots $(0.1 \mathrm{ml})$ were serially diluted in PBS and streaked on blood agar for culture and quantitation. The mean number $(\mathrm{N})$ of viable pneumococci remaining in the lung at time, $\mathrm{t}$, was divided by the number viable at $0 \mathrm{~h}(\mathrm{No})$, 
and the quotient multiplied by 100 to give the $\%$ remaining viable, or:

$$
\% \text { bacteria remaining viable }=\frac{\mathrm{Nt}}{\mathrm{N}_{0}} \times 100
$$

Dry lung weights. Standards for dry lung weights of developing rats were established by weighing lyophilized lungs of eight to 12 rats per age group on a microbalance (Cahn Instruments. Cerritos, $\mathrm{CA}$ ). The range of values obtained were as follows: ()-2 days of age $(0.024-(0.028 \mathrm{~g}) ; 3-5$ days $(0.035-0.036 \mathrm{~g}): 6-8$ days $(0.059-(0.060 \mathrm{~g}): 13-15$ days $(0.093-(0.096 \mathrm{~g}): 20-22$ days $(0.120-$ $(0.124 \mathrm{~g}) ; 4 \mathrm{wk}(0.155-0.165 \mathrm{~g}) ; 5 \mathrm{wk}(0.193-0.196 \mathrm{~g}) ; 6 \mathrm{wk}$ $(0.300-0.311 \mathrm{~g})$ and $>4$ months $(0.330-(0.390 \mathrm{~g})$.

Histology. Lungs were fixed in $10 \%$ buffered formaldehyde. impregnated with paraffin, and the sections stained with hematoxylin and eosin for light microscopy.

Bronchoalverolar lavage. Rats were killed with an overdose of pentobarbital i.p. and bronchoalvecolar lavage was carried out as described previously (6). In brief, the trachea was exposed, incised, and tubing was inserted and attached to a syringe holder (19-gauge Butterfly. Abbott Hospitals, Chicago. IL). A tie was placed to secure the catheter, and the trachea above the catheter was occluded with a hemostat. Cold sterile PBS was injected into the catheter and withdrawn for two cycles. After the procedure was repeated the $(w 0)$ volumes were pooled. The volumes of PBS used for each cycle of lavage in the different age groups were as follows: $(0$ - to 6 -day-old-rats $(0.20 \mathrm{ml}): 7-1.3$ days $(0.35 \mathrm{ml}): 14-$ 20 days $(0.75 \mathrm{ml}): 2 \mathrm{l}-27$ days $(1.0 \mathrm{ml}): 4 \mathrm{wk}(1.5 \mathrm{ml}): 5 \mathrm{wk}(3.0$ $\mathrm{ml})$; and $\geq 6 \mathrm{wk}(5.0 \mathrm{ml})$. The volume of lavage fluid recovered $(\sim 75 \%$ of the original volume in all age groups) was recorded and a leukocyte count was performed. Leukocytes were removed by centrifugation and stained with Wright's stain for the differential leukocyte count and with $\alpha$-naphthol acetate esterase (Sigma Chemical Corp.. St. I.ouis, MO) for detection of nonspecific esterase activity.

Complement receptors. Complement receptors were detected by use of erythrocyte complexes as previously described (7.8). Briefly, sheep erythrocytes (I:) were coated with IgM anti-Forssman antibody $\left(E \Lambda_{M}\right)$ (Cordis Laboratories. Miami. FL), and the complexes were mixed with a dilution of fresh rat serum that yielded approximately $50 \%$ hemolysis in $30 \mathrm{~min}$ at $37^{\circ} \mathrm{C}$ to give E $\Lambda_{M} C$. F $\Lambda_{M} C$ contained $C 3$ almost entirely as i( $3 b$ (7). Leukocytes from bronchoalveolar lavage fluid ( $>95 \%$ macrophages by morphology and nonspecific esterase staining) were suspended in RPMI with $10 \%$ heat-inactivated fetal calf serum with gentamicin sulfate (Sigma Chemical Co.. St. Louis, MO), penicillin G and streptomycin sulfate (CIBCO, Grand Island. NY) to a concentration of $5 \times 10^{6}$ cells $/ \mathrm{ml}$, and $0.2 \mathrm{ml}$ of the suspension was added to wells on glass slides (I ab Tek. Miles Laboratories. Inc.. Napierville, IL). After 2 h, nonadherent cells were removed by washing, and $\mathrm{E} \Lambda_{\mathrm{M}} \mathrm{C}^{\circ}\left(1 \times 10^{7}\right.$ in $(0.5 \mathrm{ml})$ were added. After 30 min at $37^{\circ} \mathrm{C}$ nonadherent $\mathrm{E} \wedge_{\mathrm{M}} \mathrm{C}$ were removed by washing and 200 or more macrophages per well were examined for formation of rosettes. Macrophages with three or more complexes attached were considered positive for (-receptors.

Chemotaxis. I cukocyte-free lavage fluids were prepared from adult rats (one rat per lavage sample) and from rats aged $<1$ day (six rats per pool). The fluids were stored at $-70^{\circ} \mathrm{C}$ and thawed only once, just before use.

Granulocytes were isolated from $140 \mathrm{ml}$ of human peripheral venous blood (21 to 35-year-old. nonsmoking. male volunteers) by use of dextran (average mol wt 234.000) sedimentation of heparinized whole blood, separation of the granulocytes and mononuclear cells by the Hypaque-Ficoll technique, and hypotonic saline lysis of residual erythrocytes (9-11). The granulocyte suspensions were more than $93 \%$ pure and viability was $\geq 95 \%$ as determined by trypan bluc exclusion. For labeling with ${ }^{51} \mathrm{Cr}$ (12), granulocytes were suspended in Gey's balanced salt solution without bovine serum albumin to give a final concentration of
$2.0 \times 10)^{7}$ cells $/ \mathrm{ml} .{ }^{51} \mathrm{Cr}$ (as sodium chromate) was added to the cell suspension (2 $\mu$ (i/ $10^{\circ}$ granulocvtes) and incubated with agitation at $37^{\circ} \mathrm{C}$ for $1 \mathrm{~h}$ in an atmosphere of $95 \%$ air and $5 \%$ C(). The incubation was stopped by adding cold Gev's medium. The "Cr-labeled leukocytes were collected by centrifugation at $5^{\circ} \mathrm{C}$. washed three times with cold Gey's medium, and resuspended in Gey`s medium with $2 \%(\mathrm{w} / \mathrm{v})$ bovine serum albumin. Cell counts were determined with a Coulter counter (model ZBI) and the granulocyte concentration adjusted to $3 \times 10^{\circ}$ cells $/ \mathrm{ml}$.

Chemotaxis assavs were done using blind well chambers. Two membrane filters (a $5-\mu \mathrm{m}$ pore size top filter and a $3-\mu \mathrm{m}$ pore size bottom filter) were used to separate the two compartments of the blind well chamber. ${ }^{5} \mathrm{Cr}$-labeled granulocytes $(0.2 \mathrm{ml}$ at a concentration of $3 \times 10^{6}$ cells $/ \mathrm{ml}$ ) were placed in the upper compartment, and lavage buffer alone, chemotactic standard or lung lavage fluid $(0.2 \mathrm{ml})$ in the lower compartment. For each assay, dose-response curves were generated using FMLP as the standard chemotactic agent at concentrations of () (random movement control). $1 \times 10^{-6)} .5 \times 10^{-6}, 1 \times 10^{-8}$, and $5 \times 10^{-8}$ $\mathrm{mol} / \mathrm{liter}$. All chemotaxis assays were done in triplicate chambers. After $3 \mathrm{~h}$ of incubation at $37^{\circ} \mathrm{C}$ in an atmosphere saturated with water and containing $95 \%$ air and $5 \%$ carbon dioxide. the contents of the upper compartment were aspirated and the filters removed. The filter on the attractants side was dip rinsed 10 times in isotonic saline. Its radioactivity was determined with a $\gamma$-counter and expressed as corrected counts/min adjusting for the radioactivity of the labeled granulocytes (mean of 10.000$)$ $\mathrm{cpm} / 10^{6}$ cells) as previously described (10, 12). (hemotaxis results were expressed as mean $\mathrm{cpm}$ for triplicate samples after subtraction of counts for random migration. The intraassay variation averaged $\pm 10.7 \%$ from the mean. and the interassay variation was $\pm 21.9^{\circ} \mathrm{c}$.

Statistical analysis. Data were analyzed with the $t$ test or by the Mann-Whitney U test, as appropriate.

\section{RESUI.TS}

Pneumococeal clearance. Bacterial slurries containing approximately $10^{8}$ viable pneumococci per $\mathrm{ml}$ were nebulized for 30 min into an acrosol chamber in which developing and adult rats had been placed. At the end of the period of bacterial inhalation $(0 \mathrm{~h})$. rats were killed at intervals and the number of viable pneumococci remaining in their lungs was determined. Pulmonary pneumococcal clearance was strikingly different in adult and developing rats over a $24-h$ period. Studies with type 25 pneumococci (Fig. 1) showed that adult rats could clear the bulk of inhaled pneumococci within $90 \mathrm{~min}$, whereas there was net bacterial growth at this time in the lungs of rats that were $<1$ day old. The ability of the latter to clear pneumococci was significantly lower at all times compared with adults $(p<0.01)$. Six-day-old rats did achieve significantly $(p<0.02)$ better clearance of type 25 pneumococei than did $<1$-day-old rats, but the 6-day-old rats also had depressed clearance throughout the study period compared with adults $(p<0,(01)$. Results with tipe i pneumococei were similar (Fig. 1). Whereas adult rats cleared the bulk of type 1 pneumococei within $24 \mathrm{~h}$, there was striking proliferation of these organisms in $<2$-day-old rats, and 7-dayold rats had an intermediate level of clearance. Differences in clearance of type 1 pneumococci among adult rats and developing rats were significant at all times $(p<0.02)$, and the 7 - and $<2$-day-old rats also differed significantly from each other at 4 and $24 \mathrm{~h}(p<0.01)$.

Despite the marked depression in clearance of inhaled type 1 and type 25 pneumococci, neonatal rats never showed obvious respiratory distress after pneumococcal acrosols, and they remained active and nursed normally. When neonatal rats were killed at $24 \mathrm{~h}$ after inhalation of type 1 or type 25 pneumococci. none had gross evidence of pulmonary consolidation. To determine if newborn rats observed longer than $24 \mathrm{~h}$ would develop evidence of pneumonia. 12 rats aged $<1$ day were exposed to 
aerosols of type 25 pneumococci and observed for a 2 -wk period; all remained well. Six were killed at $1 \mathrm{wk}$ after the aerosol exposure, and the other six were killed after $2 \mathrm{wk}$. None of these rats had detectable pulmonary consolidation grossly or microscopically and cultures of the lungs were sterile. These findings indicated that despite the marked impairment of early clearance in developing rats, host defenses operating after $24 \mathrm{~h}$ eliminated inhaled type 25 pneumococci.

To compare clearance as a function of developmental age in greater detail, rats ranging in age from $<1$ day to 4 wk were exposed to aerosols of type 25 pneumococci and clearance was measured $30 \mathrm{~min}$ after deposition of pneumococci. The results (Table 1) showed that clearance was lower in all developmental

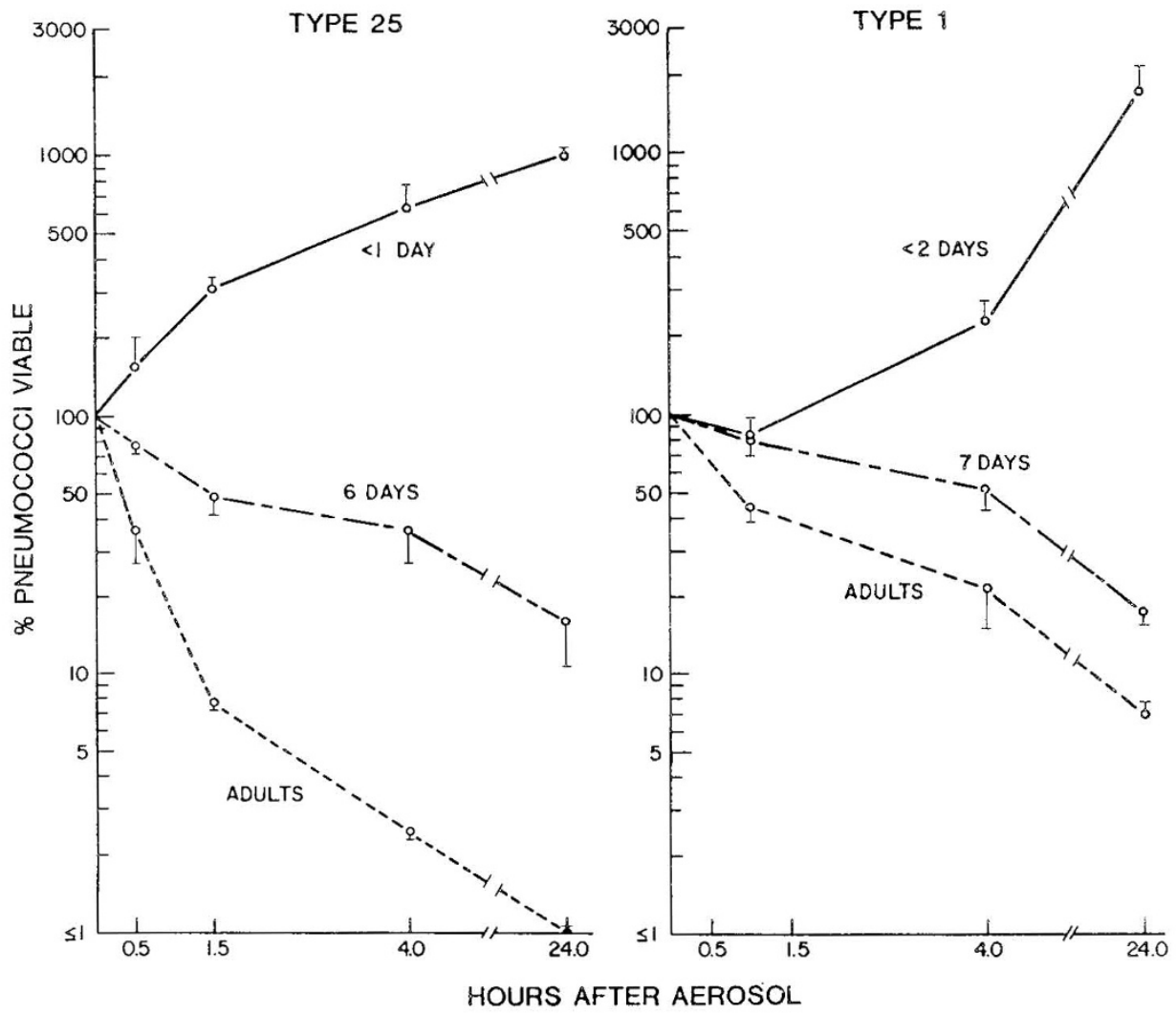

Fig. 1. Clearance of inhaled pneumococci by developing rats. Points represent means \pm SE for seven to 15 rats in each age group at each time period. The mean number of viable pneumococci deposited in the lungs was not significantly different at different ages, and ranged from $4.7 \times 10^{5}-$ $7.1 \times 10^{5} / \mathrm{g}$ of wet lung tissue for type 25 pneumococci and from $1.5 \times 10^{6}-3.1 \times 10^{6}$ for type 1 pneumococci. Clearance of type 25 or type 1 pneumococci in developing rats was significantly less than in adults at all times $(p<0.02)$.

Table 1. Age-related differences in clearance of type 25 pneumococci in rats

\begin{tabular}{|c|c|c|c|c|c|}
\hline \multirow[b]{2}{*}{ Age } & \multirow[b]{2}{*}{ No. litters } & \multicolumn{2}{|c|}{ Zero time } & \multicolumn{2}{|c|}{$30 \mathrm{~min}$ after aerosol } \\
\hline & & No. rats & $\begin{array}{c}\text { Pneumococci } \\
\text { deposited }\left(\times 10^{5}\right) \\
\text { per g lung* }\end{array}$ & No. rats & $\begin{array}{c}\text { Pneumococci } \\
\% \text { viable }\end{array}$ \\
\hline$<1$ day & 2 & 13 & $5.82 \pm 1.28 \dagger \ddagger$ & 13 & $111 \pm 10 \div \S$ \\
\hline 1 day & 2 & 10 & $5.10 \pm 1.20 \ddagger$ & 13 & $115 \pm 23 \S$ \\
\hline 2 days & 2 & 12 & $5.70 \pm 1.50 \div$ & 13 & $73 \pm 10 \S$ \\
\hline 4 days & 2 & 10 & $3.75 \pm 1.00 \div$ & 9 & $62 \pm 16 \S$ \\
\hline $5-6$ days & 2 & 9 & $2.29 \pm 0.95 \ddagger$ & 8 & $76 \pm 10 \S$ \\
\hline $7-8$ days & 3 & 13 & $2.67 \pm 0.74 \ddagger$ & 15 & $54 \pm 4 \S$ \\
\hline 2-4 wk & 3 & 14 & $2.28 \pm 0.37 \ddagger$ & 15 & $67 \pm 4 \S$ \\
\hline Adult ( $\geq 4 \mathrm{mo}$ ) & 2 & 8 & $3.09 \pm 0.20$ & 10 & $34 \pm 4$ \\
\hline
\end{tabular}

* Wet lung wt.

$\dagger$ Mean \pm SE/rat.

$\ddagger$ Not significantly different from adult $(p>0.05)$.

$\S$ Significantly different from adult $(p<0.05)$. 
opmental age. Alveolar macrophages obtained from rats during their first few days of life frequently contained a multitude of pale cytoplasmic inclusions; these inclusions were not seen in rats older than 1 wk.

Quantitative counts of macrophages in lavage fluids revealed striking differences between adults and neonates (Table 2). Rats that were less than 1 day old had fewer than $1 / 10$ the number of alveolar macrophages of adults. even when differences in lung weight were taken into account. The number of macrophages per $g$ of lung tissue increased steadily with age and by 4 wk approached the number in adults.

Immune receptors of macrophages of developing rats were evaluated by determining the percent of alveolar or peritoneal macrophages that would form rosettes with $\mathrm{E} \wedge_{M} \mathrm{C}$ (Table 3). The percent of resident alveolar macrophages of adults that formed rosettes with $\mathrm{E} \wedge_{\mathrm{M}} \mathrm{C}$ was low compared with peritoneal macrophages, as previously reported $(9,10)$. Resident alveolar macrophages of developing rats, however, formed even fewer $\mathrm{EA}_{\mathrm{M}} \mathrm{C}$ rosettes than their adult counterparts. whereas peritoneal macrophages from neonates and adults formed rosettes equally well.

Gramulecyte recruitment. In adult mice, granulocytes have been shown to play an important role in the clearance of inhaled pneumocoeci within several hours after pneumococcal deposition in the lung (14-16). I evels of granulocytes in neonatal lungs after pneumococcal acrosols were, therefore, of interest. Preliminary information on granulocyte movement into lungs after type 25 pneumococcal acrosols was obtained by histologic examination of hematoxylin and cosin-stained sections of lungs. Seven unchallenged adults and seven newborn rats were examined to provide baseline information. These rats had no granulocytes in their alveoli and few in the interstitium. After pneumococcal challenge (average of $2.1 \times 10^{6}$ viable pneumococei per adult lung) seven adult rats that were studied at I h showed a few granulocytes in the pulmonary interstitium. and another seven, studied at $24 \mathrm{~h}$. showed occasional alveolar as well as interstitial granulocytes. Newborn rats studied in parallel with the adults (also seven in each group) showed no detectable granulocytes in lung sections obtained before or at $1 \mathrm{~h}$ after pneumococeal challenge, and the number in sections obtained at $24 \mathrm{~h}$ appeared to be less than in adults. To obtain quantitative information on granulocyte influx. lavage was carried out on rats exposed to aerosols of type 25 pneumococci. and total and differential counts of leukocytes in lavage were carried out. Results (Fig. 2) showed that rats in all age groups had numbers of granulocytes immediately following pneumococcal challenge $(0 \mathrm{~h})$, but by $4 \mathrm{~h}$ adult rats had a significant increase in the number of granulocytes in their lavage. One-week-old and $<1$ day-old rats mounted a signilicant granulocyte response within $24 \mathrm{~h}$ after pneumococcal challenge. but the number of granulocytes in lavage fluids of < 1 -day-old rats was consistently lower than in fluids from adults or 1 -wk-old rats. In all age groups. alveolar macrophages remained the predominant cell type. and adults had significantly more macrophages per g lung weight at all times compared with newborn rats or 1 -wk-old rats. Adults also had more lymphocytes, but the differences did not reach significance.

(hemolactic activity of lavage. To determine if differences in granulocyte recruitment in neonatal and adult rats were associated with differences in chemotactic activity in lavage fluids. adult and 1-day-old rats were exposed to acrosols of type 25 pneumococei and their leukocyte-free lavage fluids were tested for chemotactic activity. Lavage was carried out using a comparable ratio of lung weight to lavage volume for adults $(0.035 \mathrm{~g} /$ $\mathrm{ml}$ ) and $<1$-day-old rats $(0.051 \mathrm{~g} / \mathrm{ml})$. Leukocyte-free fluids from the neonatal rats were pooled (six lavages/pool) to allow an adequate working volume for triplicate assays of chemotactic activity. Fluids from adults were tested without pooling. The assays were carried out in blind well chemotactic chambers with "Cr labeled human granulocytes. The results (Fig. 3) showed that adults had increased chemotactic activity after pneumococcal aerosols. The activity peaked at $4 \mathrm{~h}$ and the activity (following 30) min of bacterial inhalation and a 1()-min period to flush the aerosol chamber) at 0 and at $4 \mathrm{~h}$ was significantly higher than the activity observed in lavage fluids of unchallenged adults. In contrast. neonatal lavages showed no significant change in activity after pneumococcal aerosols compared with unchallenged neonates.

\section{DISC USSION}

In the present studies the ability of neonatal rats to clear pneumococci from the lungs was evaluated. This model. which provided a diffuse but sublethal inhalational challenge, showed that neonatal rats had impaired net clearance of inhaled pneumocoeci. Impairment was most marked in the immediate postnatal period. but some impairment persisted for the first it wh after birth. These observations are consistent with results obtained by Sherman et al. (1, 2) who found that inhaled staphylococei are cleared more slowly in rabbits at 1 day after birth

Table 3. Percent of alveolar and peritoneal macrophases that formed rosettes with $\mathrm{E}_{11} \mathrm{C}^{\mathrm{C}}$

\begin{tabular}{|c|c|c|}
\hline $\begin{array}{l}\text { No. of pools } \\
\text { or }\end{array}$ & \multicolumn{2}{|c|}{$\begin{array}{c}\% \text { Macrophages rosetting } \\
\text { with } 1 \mathrm{~A}_{\mathrm{M}} \mathrm{C}\end{array}$} \\
\hline tested & Alreolar & Peritoneal \\
\hline 5 & $1.2 \pm 1.0 \%$ & \\
\hline 3 & $3.1 \pm 1.21$ & $81.5 \pm 3.18$ \\
\hline 5 & $1.6 \pm 0.3+$ & $78.8 \pm 0.7 \%$ \\
\hline 6 & $1.4 \pm 0.7+$ & $87.0 \pm 3.58$ \\
\hline 3 & $6.8 \pm 1.1 \%$ & $80.2 \pm+60$ \\
\hline 6 & $11.6 \pm 2.5$ & $84.8 \pm 2.8$ \\
\hline
\end{tabular}

* Macrophages in the amniotic fluid of unborn. term fetuses were tested.

+ Significantly different from adult $(p<0 .(05)$.

+ Vot significantly difierent from adult $(p>0.05)$.

Table 2. Number of alveolar macrophages in bronchoalvenlar lavage fluid of developing rats (mean \pm st:)

\begin{tabular}{|c|c|c|c|c|}
\hline & & \multicolumn{3}{|c|}{ Macrophages $\times 10^{5}$} \\
\hline & \multirow{2}{*}{$\begin{array}{l}\text { No. of pools } \\
\text { or rats } \\
\text { tested }\end{array}$} & & \multicolumn{2}{|c|}{ Perglung } \\
\hline$\wedge \mathrm{ge}$ & & Per rat & Wet wt & Dry wt \\
\hline$<1$ day & 12 & $0.20 \pm 0.02$ & $1.56 \pm 0.18^{*}$ & $7.49 \pm 0.84^{*}$ \\
\hline I wk & 7 & $0.81 \pm 0.25$ & $2.41 \pm 0.74^{*}$ & $13.76 \pm 4.24 *$ \\
\hline $2 w k$ & 7 & $2.47 \pm 0.86$ & $5.15 \pm 1.79 *$ & $26.60 \pm 9.3(0)^{*}$ \\
\hline $3 \mathrm{wk}$ & 14 & $6.30 \pm 0.63$ & $10.40 \pm 1.07 *$ & $51.66 \pm 5.200^{*}$ \\
\hline $4 \mathrm{wk}$ & 5 & $10.96 \pm 1.28$ & $15.13 \pm 1.29 \%$ & $68.51 \pm 6.744$ \\
\hline$\wedge$ dult $(\geq 4 \mathrm{mo})$ & 12 & $27.8 \pm 3.74$ & $15.71 \pm 1.51$ & $81.82 \pm 7.01$ \\
\hline
\end{tabular}

* Significantly different from adult $(p<0.05)$.

$\dagger$ Not significantly different from adult $(p>0.05)$. 

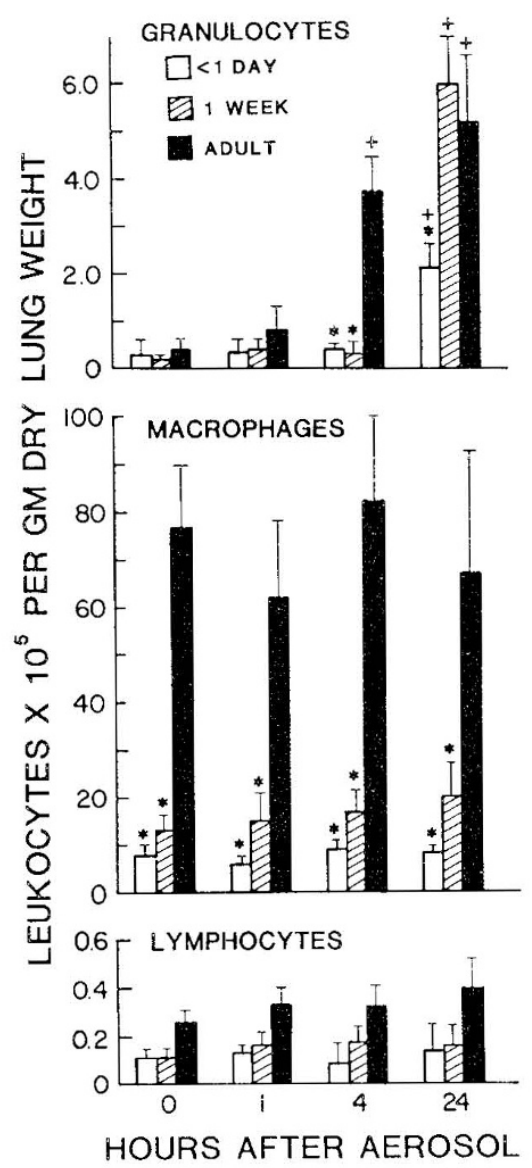

Fig. 2. Leukocytes in lung lavage fluids of rats following inhalation of type 25 pneumococci. Bars indicate the mean number $( \pm \mathrm{SE})$ of leukocytes per g dry lung tissue. Six to 14 rats were studied in each age group at each time period. Values that were significantly different from adults are indicated with an asterisk $(p<0.05)$ and values significantly different from rats of the same age at $0 \mathrm{~h}$ are indicated with a cross $(p<$ 0.05 ). The number of viable pneumococci deposited per $g$ of dry lung tissue for rats less than 1-day-old, 1 -week-old, or adults ( $\geq 4$ months old) were $5.5 \pm 2.3 \times 10^{6}, 7.4 \pm 3.8 \times 10^{6}$, and $8.6 \pm 2.5 \times 10^{6}$, respectively. These differences in inocula were not significant $(p>0.05)$.

than at 7 or 14 days of age, and that inhaled group B streptococci actually proliferate in the lungs of 1-day-old rabbits.

Quantitation of leukocytes in bronchoalveolar lavage fluids in the present studies revealed that newborn rats, like neonatal rabbits and monkeys $(3,17)$, had markedly fewer resident alveolar macrophages per $\mathrm{g}$ of lung tissue than did adults. The number of resident alveolar macrophages in rats increased steadily after birth and reached adult levels at about 4 wk of life. Low numbers of resident alveolar macrophages certainly might have contributed to impaired clearance of pneumococci, considering the important role these cells have in clearance of several other bacterial species following aerosols (13). Alveolar macrophages may play a central role in killing inhaled pneumococci either by phagocytosis and intracellular killing, or, as discussed below, via antibacterial secretory products (18).

The efficacy of neonatal alveolar macrophages in phagocytes and killing of pneumococci in vitro has not been reported to our knowledge. Such studies would be difficult to carry out because neonatal rats have a very low total number of resident alveolar macrophages compared with adults or with neonates of larger species, such as rabbits. Studies of the phagocytosis of Staphylococcus aureus, Escherichia coli, and Candida in vitro by rabbit neonatal alveolar macrophages suggest that neonatal macrophages are about as effective in phagocytosis of these pathogens as are adult macrophages $(4,19)$. However, macrophage uptake

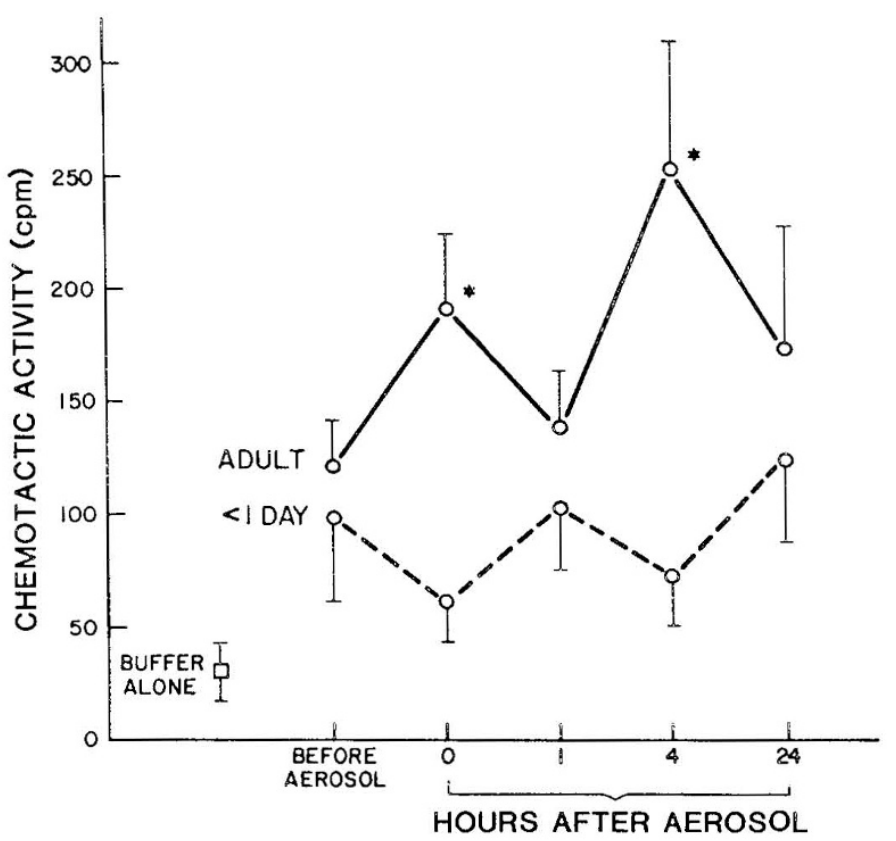

Fig. 3. Chemotactic activity of bronchoalveolar lavage fluids of neonatal and adult rats before and after challenge with aerosolized type 25 pneumococci. Each point represents the mean activity $( \pm$ SE) obtained with six to 14 individual adult or pooled neonatal lavage fluids. Activity is expressed as cpm of ${ }^{51} \mathrm{Cr}$-labeled human granulocytes attracted by 0.20 $\mathrm{ml}$ lavage fluid after correction for random activity. Values after aerosol exposure that were significantly different from the unchallenged rats in the same age group are marked with an asterisk $(p<0.05)$.

of inhaled $S$. aureus in vivo appears to be less in neonatal rabbits than in adults (26), and lapine neonatal alveolar macrophages show less chemotactic and microbicidal activity than adult macrophages both in vitro (19) and in vivo (1,2). Other studies indicate that postphagocytic oxidative metabolism and superoxide release is not as well developed in alveolar macrophages of neonates compared with adults either in rabbits (20 or in guinea pigs (21). Thus, to the extent that rat neonatal alveolar macrophages resemble those of other species, they may have less microbicidal activity than macrophages of adults.

Abnormalities of immune receptors of neonatal rat alveolar macrophages have been described (22). In the present study, we were able to confirm that neonatal rat alveolar macrophages have significantly fewer $\mathrm{C} 3$ receptors detectable by rosetting with $\mathrm{EA}_{\mathrm{M}} \mathrm{C}$ than do adults. However, the relevance of this finding to impaired clearance of inhaled pneumococci in neonatal rats is uncertain. Even in adult rats only a minority of alveolar macrophages will bind $\mathrm{EA}_{\mathrm{M}} \mathrm{C}$ or pneumococci opsonized with complement $(7,8)$, and depletion of circulating $\mathrm{C} 3$ in rats has little effect on early clearance of inhaled pneumococci (23).

The present studies extend previous observations on mechanisms of clearance of bacterial aerosols in the neonatal lung by showing that there is impairment in the development of the inflammatory response to inhaled pneumococci and impaired movement of granulocytes into the lungs of developing rats. These defects were most marked in rats aged less than 1-day, but 7-day-old rats also showed impairment. The degree of the defect in granulocyte recruitment correlated well with the degree of impairment in pneumococcal clearance. It has been documented in adult mice that movement of granulocytes into the lung is critical for eventual killing of pneumococci that escape destruction by resident alveolar macrophages or extracellular antibacterial factors (14-16). Although the present observations are the first that deal with the pulmonary granulocytic response to pneumococcal aerosols in neonates, analogous studies have been done on clearance of group B streptococci from the peritoneal 
space in a murine neonatal model. In those studies. impaired peritoneal clearance was associated with delayed recruitment of granulocytes (24). Despite the host deficiencies demonstrated in the present studies, even newborn rats were able eventually to eliminate inhaled pneumococci without any mortality. The reason for this favorable outcome is not certain. but may have been due to the fact that rats in each of the age groups were able eventually to develop a degree of pulmonary inflammation.

The delay in recruitment of granulocytes into the lung after pneumococcal aerosols in the present studies was shown to be associated with poor generation, or conceivably inhibition. of chemotactic activity in the lungs of neonatal rats. Pneumococci themselves may provide a weak chemotactic stimulus to granulocytes, but they lack endotoxin and do not provide the same level of chemotactic stimulus as seen with gram-negative bacilli. In adult mice it has been demonstrated that $\mathrm{C} 5$ is an important source of chemotactic activity in the lung after pneumococcal challenge, and pulmonary granulocyte recruitment after pneumococcal challenge is significantly less in genetically $\mathrm{C} 5$-deficient mice that in their (5-sufficient counterparts (15). Chemotactic factors other than $C 5$ also appear to be important in eliciting a granulocyte influx into the lungs, in that genetically C 5 -deficient mice are able to develop appreciable chemotactic activity in bronchoalveolar lavage fluids after pneumococcal challenge (15). Phagocytosis by alveolar macrophages is accompanied by release of chemotactic factors that are distinct from C5a (25-28). and these factors could be a source of chemotactic activity in the alveoli after bacterial acrosols. One would expect lower levels of macrophage-derived chemotactic factors in developing animals simply because of the low numbers of alveolar macrophages in the early stages of postnatal development. Increased levels of chemotactic inhibiting activity have been found in the cord blood and serum of newborn humans (29), but the role of chemotactic inhibitors in the lung, if any, has not been established.

Poor granulocyte recruitment to the lungs in neonates could be a consequence of low granulocyte reserves or functional defects of granulocytes which have been noted in developing animals and in man (30-38). Hyde ot al. (39), using a rabbit model, have found that neonatal granulocytes are deficient in their ability to emigrate into the alveolar spaces of adult rabbits challenged with C5f. These investigators, however, suggest that unique features of the alveolar and vascular anatomy of the neonatal lung may help to compensate for functional deficiencies of neonatal granulocytes. Additional studies will be needed to determine whether intrinsic granulocyte deficiencies contributed to the impaired granulocyte response in neonatal rats after pneumococcal aerosols. The lower chemotactic activity of neonatal rat lavage in the present studies was separable from possible functional defects of neonatal rat granulocytes, because adult human granulocytes were used in the chemotactic assays.

Although phagocytosis and intracellular killing of inhaled pneumococci by granulocytes appears to play an important role in the eventual sterilization of the alveoli, the bulk of inhaled pneumococei $(80-90 \%$ of the inoculum) are cleared within 45 to $60 \mathrm{~min}$ after deposition, and there is increasing evidence that much of this early killing may take place extracellularly (23, 40), 41). Several extracellular factors have been found in bronchoalveolar lavage fluid which could contribute to the extracellular killing of pneumococci, including lysozyme, peptides, transferrin, lactoferrin, and free fatty acids $(18,42)$. Lysozyme and transferrin are secreted by alveolar macrophages, and lipoprotein lipase, another alveolar macrophage secretory product, can release free fatty acids from triglycerides (18). Surfactant contains triglyceride and lipoprotein lipase along with antipneumococcal free fatty acids $(18,42,43)$. Recently, we found that there is an age-related deficiency in the antipneumococcal activity of bronchoalveolar lining material of developing rats (44). In these studies the mean bactericidal titer of lining material from adult rats for pneumococci was 1:40, whereas the same amount of lining material from newborn rats had no antipneumococcal activity. Bactericidal activity increased with developmental age and normal levels were reached at about 4 wk of age. L-ysozyme levels in lavage fluids from newborn rats were markedly lower than in adults $(p<0.01)$ and free fatly acid levels were moderately lower $(p<0.1)$. Studies are currently in progress to determine whether these differences affect clearance of inhaled pneumococei in viro and whether macrophages play a role in production of antipneumococcal factors within the alveoli.

Acknowledgments. The excellent technical assistance of Steven Marple and Michael Goolsby is gratefully acknowledged.

\section{REFFRE: $\mathrm{YCH}$}

1. Sherman M. Goldstein F. I ippert W. Wennberg R 1977 Veonatal lung defense mechanisms: a study of the alveolar macrophage system in neonatal rabhits Am Rev. Respir Dis 116:433-4.40

2. Sherman M. Goldstein F. L.ippert W. Wennberg R 1982 (iroup B streptecoceal lung infection in neonatal rabbits. Pediatr Res $16: 204-21$ ?

3. Zeligs BJ. Nerurkar LS. Bellanti JA 1977 Maturation of the rabbit alveolar macrophage during animal development. I. Perinatal influx into alveoli and ultrastructural differentiation. Pediatr Res 11:197-208

4. Zeligs BJ. Nerurkar IS. Bellanti JA 1977 Maturation of the rabbit alveolar macrophage during animal development. III. Phagocytic and bactericidal functions. Pediatr Res $11: 1208-1211$

5. Rehm SR. Coonrod JD 1982 Earl clearance of pneumesoce from the lungs of decompiemented rats. Infect Immun 36:24-29

6. Coonrod JD). Yoneda K 1981 Complement and onsonins in alveolar secretions and serum in experimental pneumococca! pneumonia. Rev Infeet I is 3:310322

7. (Conrod Ji). Yoneda $\mathrm{K} 198.3$ IEftect of rat alveolar lining material on macro phage receptors. $J$ Immunol 1.30:2589-2596

8. Coonrod JD, Rehm SR 1982 Complement receptors of rat alveolar macrophages. J Reticulocndothel Soc 31:107-11:

9. Boyum A 1968 Isolation of mononuclear cells and granulocyies from human blood. Scand J (lin 1.ab Invest 21 (suppl 97):77-84)

10. Bridges RB. Kraal JH. Huang IJT. Chanceilor MB 1977 fiffects of tobaceo smoke on chemotaxis and glucose metabolism of polymorphonuclear leukocrtes. Infect Immun 15:115-123

11. Clark RA. Kimball HR 1971 Defective granulocyle chemotaxis in the (hadiakHigashi syndrome. J Clin Invest 50:2645-26.52

2. (jallin JI. Clark RA. Kimball HR 1973 (iranulocyte chemotaxis: an improwed in vitro assay emploving "Cr-labeled granulocites. J Immunot 110:122-14()

13. Goldstein EW Lippert W. Warshauer D) 1974 Pulmonary afleolar macrophaye. Defender against bacterial infection of the lung. J (lin Invest $54.519 \ldots 528$

14. Pierec AK. Reynolds RC. Harris (il) 1977 lecukocytic response to inhaled bacteria. Am Rev Respir Dis 1 16:679-684

15. Towes GB, Vial WC 1984 The role of $C^{5}$ in polymorphonuckear keuhocre

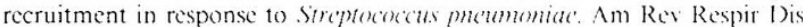
$129: 82-86$

16. Vial WC. Towes (iB. Pierce AK 1984 Farly pulmonary granulocste recruit

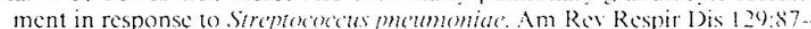
ment

17. Jacobs RF. Wilson CB. Palmer S, Springmeyer SC, Henderson WR. (ilower DM. Kessler DI. Jr. Murphy JH. Hughes JP. Van Belle (i. (hi IY. I lodson WA 1985 Factors related to the appearance of alveolar macrephages in the developing lung. Am Rev Respir I is 131:548-553

18. Coonrod JD) 1986 The role of extracellular bactericidal factors in putmonary host defense. Semin Respir Infect 1:118-129

19. Zeligs BJ. Nerurkar L.S. Bellanti JA 1984 Chemotactic and candidacidal responses of rabbit alveolar macrophages during postnatal development and the modulating roles of surfactant in these responses. Infect Inmun 44:374) 385

20. Sherman MP. 1.ehrer RI 1985 Oxidative metabolism of neonatal and adult rabbit lung macrophages stimulated with opsonised group $B$ streptexocci Infect Immun 47:26-30

21. 7.eidler RB. Kim HD 1985 phagocstosis, chemiluminescence, and cell volum of alveolar macrophages from neonatal and adult guinea pigs. I I cuk Biol 37:29-43

22. Kradin RI. Mec arthy K.M. Schnecherger EF: 19860 Opsonic receptor function is reduced on the surface of newborn alveolar macrophages. Am Rev Respi Dis 133:238-24t

23. Rehm SR. Coonrod JD 1982 Farly clearance of pneumecoce from the lungs of decomplemented rats. Infect Immun 36:24-29

24. Schuit KF. DeBeasio R 1980 Kinetics of phagocste respense to group $B$ streptococcal infections in newborn rats. Infeet Immun 28:319-5.34

25. Gadek JF. Hunninghake (jW. Zimmerman RI. Crystal R( ; 1980 Regulation of the release of alveolar macrophage-derived neutrophil chemotactic factor Am Rev Respir Dis 21:723-733

26. Hunninghake (jW. Gadek Jt: Fales HM, Cristal R( 1980 H Human alveolat macrophage-derived chemotactic factor for neutrophils. J ('lin Invest $66: 473-483$

27. Merrill WW, Naegel (jP. Matthay RA. Revnolds HY 1980) Alveolar macro- 
phage-derived chemotactic factor. J Clin Invest 65:268-276

28. Valone FH, Franklin M, Sun FF, Goetzl EG 1980 Alveolar macrophage lipoxygenase products of arachidonic acid. Isolation and recognition as the prominent constituents of the neutrophil chemotactic activity elaborated by alveolar macrophages. Cell Immunol 54:390-401

29. Tannous R, Spitzer RE, Clarke WR, Goplerud CP, Cavendar-Zylich N 1982 Decreased chemotactic activity in activated newborn plasma. Role of higher chemotactic factor inactivator activity and lower complement levels. J Lab Clin Med 99:331-341

30. Christensen RD, Rothstein G 1980 Exhaustion of mature marrow neutrophils in neonates with sepsis. J Pediatr 96:316-318

31. Christensen RD, Shigeoka AO, Hill HR, Rothstein G 1980 Circulating and storage neutrophil changes in experimental type II group B streptococcal sepsis. Pediatr Res 14:806-808

32. Andersen DC, Hughes BJ, Smith CW 1981 Abnormal mobility of neonatal polymorphonuclear leukocytes. Relationship to impaired redistribution of surface adhesion sites by chemotactic factor or cholchicine. J Clin Invest 68:863--874

33. Boner A, BJ Zeligs, Bellanti JA 1982 Chemotactic responses of various differential stages of neutrophils from human cord and adult blood. Infect Immun 35:921-928

34. Fontan G, Lorente F, Carcia Rodriquez MC, Ojeda JA 1981 In vitro human neutrophil movement in umbilical cord blood. Clin Immunol Immunopathol 20:224-230
35. Klein RB, Fischer TJ, Gard SE, Biberstein M, Rich KC, Stiehm ER 1977 Decreased mononuclear and polymorphonuclear chemotaxis in human newborns, infants, and young children. Pediatrics 60:467-472

36. Mease AD, Burgess DP, Thomas PJ 1981 Irreversible neutrophil aggregation A mechanism of decreased newborn neutrophil chemotactic response. Am J Pathol 104:98-102

37. Miller ME 1979 Phagocyte function in the neonate: selected aspects. Pediatrics 64:709-712

38. Strauss RG, Snyder EL 1981 Neutrophils from human infants exhibit decreased viability. Pediatr Res 15:794-797

39. Hyde DM, Downey GP, Henson PM, Giclas PC, Strunk RC 1987 Chemotactic peptide-induced polymorphonuclear leukocyte accumulation in neonatal and adult rabbit lungs. Am Rev Respir Dis 135:A25(abstr)

40. Jakab GJ 1976 Factors influencing the immune enhancement of intrapulmonary bactericidal mechanisms. Infect Immun 14:389-398

41. Coonrod JD, Marple S, Holmes GP, Rehm SR Extracellular killing of inhaled pneumococci in rats. $\mathrm{J}$ Lab Clin Med (in press)

42. Coonrod JD, Lester RL, Hsu LC 1984 Characterization of the extracellular bactericidal factors of rat alveolar lining material. J Clin Invest 74:12691279

43. King RJ, Clements JA 1972 Surface active materials from dog lung. II Composition and physiologic considerations. Am J Physiol 223:715-726

44. Coonrod JD, Jarrells M 1987 Pulmonary host defenses against pneumococci in neonatal rats. Fed Proc 46:622(abstr) 